\title{
PERBEDAAN PENYERAPAN Pb PADA BERBAGAI JENIS TANAMAN
}

\author{
Sucia Elsa Azzahri, Burhan Muslim, Muchsin Riviwanto \\ (Prodi Sarjana Terapan Sanitasi Lingkungan, Poltekkes Kemenkes Padang)
}

\begin{abstract}
Air pollution comes from many factors, one of which comes from vehicles where the smoke produced by motor vehicles contains dangerous heavy metals, Pb. Ujung Gurun Road is one of the densely populated roads which has many pollutant-absorbing plants that line the roadside. This research was conducted with the aim to determine differences in plant types in absorbing lead content $(\mathrm{Pb})$ of air on the road. Analytical research with a comparative study approach. The measurement used is the Wet Ashing Method (wet ashing) for the destruction of the sample, then analyzed using the Atomic Absorption Spectrophotometer (AAS). Data were analyzed using Anova test to see whether there were differences in Glondokan, Mahogany and Angsana plants in absorbing lead air. The results showed lead levels in leaves of glondokan plants were $0.9134 \mu \mathrm{g} / \mathrm{g}$ higher than leaves of mahogany plants as much as $0.764 \mathrm{ug} / \mathrm{g}$ and angsana $0.40 \mathrm{ug} / \mathrm{g}$. There is a significant difference in the types of plants in the absorption of air Pb levels in Jalan Ujung Gurun Padang City with $p$ value 0.002 where $p<a$. For this reason, the monday plant can be used as one of the plants that can be used as one of the government program plants for the absorption of Pb content of air produced by motor vehicles other than mahogany and angsana.
\end{abstract}

Keywords: Angsana; Glondokan; Mahogany; Lead (Pb)

\begin{abstract}
Abstrak
Pencemaran udara berasal dari banyak faktor salah satunya berasal dari kendaraan dimana asap yang dihasilkan oleh kendaraan bermotor mengandung logam berat berbahaya yaitu $\mathrm{Pb}$. Jalan Ujung Gurun merupakan salah satu jalan yang padat kendaraan yang memiliki banyak tanaman penyerap polutan yang berjejer di tepi jalan. Penelitian ini dilakukan dengan tujuan untuk mengetahui perbedaan jenis tanaman dalam menyerap kadar timbal (Pb) udara di Jalan. Penelitian Analitik dengan pendekatan studi komparatif. Pengukuran yang digunakan yaitu Metode Wet Ashing (pengabuan basah) untuk penghancuran sampel, kemudian dianalisis menggunakan Atomic Absorption Spectrophotometer (AAS). Data dianalisis menggunakan uji Anova untuk melihat adakah perbedaan tanaman Glondokan, Mahoni dan Angsana dalam menyerap timbal udara. Hasil penelitian menunjukkan kadar timbal di daun tanaman glondokan sebanyak 0,9134 $\mu \mathrm{g} / \mathrm{g}$ lebih tinggi dari daun tanaman mahoni sebanyak 0,764 ug/g dan angsana 0,40 ug/g. Ada perbedaan yang signifikan pada jenis tanaman dalam penyerapan kadar Pb udara di Jalan Ujung Gurun Kota Padang dengan $p$ value 0,002 dimana $p<$ a. Untuk itu tanaman glondokan dapat dijadikan salah satu tanaman yang bisa dijadikan salah satu tanaman program pemerintah untuk penyerapan kadar logam Pb udara yang dihasilkan kendaraan bermotor selain mahoni dan angsana.
\end{abstract}

Kata Kunci : Angsana, Glondokan, Mahoni, Timbal (Pb)

\section{PENDAHULUAN}

Udara ambien adalah udara bebas dipermukaan bumi pada lapisan troposfir yang berada di dalam wilayah yurisdiksi Republik Indonesia yang dibutuhkan dan mempengaruhi kesehatan manusia, makhluk hidup dan unsur lingkungan hidup lainnya. ${ }^{1}$ Pencemaran 
udara pada umumnya disebabkan oleh alam dan aktivitas manusia terutama dari asap kendaraan dan gas buangan industry. ${ }^{2}$ Pencemaran udara dapat terjadi akibat aktifitas manusia, salah satunnya berasal dari asap kendaraan bermotor. Hasil gas buang kendaraan bermotor terutama terjadi di jalan-jalan utama di kota-kota besar yang menjadi pusat keramaian lalu lintas. ${ }^{3}$ Menurut Peraturan Menteri Negara Lingkungan Hidup Nomor 12 Tahun 2010 Tentang Pelaksanaan Pengendalian Pencemaran Udara Di Daerah, Pencemaran udara adalah masuknya atau dimasukkannya zat, energi, dan/atau komponen lain ke dalam udara ambien oleh kegiatan manusia, sehingga melampaui baku mutu udara yang telah ditetapkan. ${ }^{1}$

Salah satu bahan pencemar yang terdapat di dalam gas buang kendaraan bermotor adalah logam berat plumbum. ${ }^{4}$ Logam berat Plumbum merupakan salah satu logam berat yang sangat berbahaya bagi makhluk hidup karena bersifat karsinogenik, dapat menyebabkan mutasi, terurai dalam jangka waktu yang lama dan toksisitasnya yang tidak berubah dan dapat mengganggu system saraf manusia. Emisi Pb yang masuk dalam bentuk gas, terutama berasal dari buangan gas kendaraan bermotor. ${ }^{3}$ Salah satu upaya yang dapat dilakukan untuk menanggulangi kandungan $\mathrm{Pb}$ udara yaitu dengan bantuan penyerapan oleh tanaman. ${ }^{5}$ Suatu tanaman dikatakan berpotensi sebagai agen bioremediasi jika mampu menyerap dan mengakumulasi pencemar tanpa mengalami gangguan pertanaman. ${ }^{6}$

Tanaman dapat disebut sebagai pereduksi logam berat $\mathrm{Pb}$ pada udara apabila mampu menyerap $\mathrm{Pb}$ namun tidak menunjukkan gejala kerusakan yang signifikan. Mekanisme masuknya partikel $\mathrm{Pb}$ ke dalam jaringan daun yaitu melalui stomata daun yang berukuran besar dan ukuruan partikel $\mathrm{Pb}$ lebih kecil, sehingga $\mathrm{Pb}$ dengan mudah masuk kedalam jaringan daun melalui proses penjerapan pasif. ${ }^{7}$ Dengan peningkatan ini, tentu saja dapat meningkatkan pencemaran lingkungan di udara karena asap dari kendaraan bermotor yang dihasilkan dari banyaknya kendaraan yang ada. Di Sumatera Barat pemerintah telah melakukan penanaman pohon sebanyak 4.142.577 batang pohon. Sedangkan untuk di Kota Padang, pemerintah sudah melakukan penanaman pohon sebanyak 408.360 batang pohon di setiap jalan-jalan yang ada di Kota Padang. Tanaman yang ditanaman oleh pemerintah yaitu tanaman mahoni dan angsana. ${ }^{8}$

Menurut peneltian Sufariz 2016, tanaman mahoni dapat menyerap kadar $\mathrm{Pb}$ udara sebanyak $1,16 \mu \mathrm{g} / \mathrm{g}$, tanaman angsana sebanyak $1,57 \mu \mathrm{g} / \mathrm{g}$, dan tanaman glondokan sebanyak $1,88 \mu \mathrm{g} / \mathrm{g}$, Dengan ini dapat dikatakan bahwa tanaman glondokan lebih banyak menyerap kadar $\mathrm{Pb}$ di udara dibandingkan tanaman Mahoni dan Angsana. ${ }^{9}$ Menurut data Badan Pusat Statistik Kota Padang, terdapat 10 Kecamatan dan 104 jalan. Di Kecamatan Padang Barat terdapat beberapa jalan salah satunya yaitu Jalan Ujung Gurun. Bedasarkan hasil survey awal, jalan Ujung Gurun tersebut banyak ditanamani pohon-pohon yang ditanam di kiri dan kanan jalan dengan berbagai jenis pohon seperti, pohon Mahoni ( 59 
batang ), Angsana ( 37 batang ), Glodokan ( 21 batang ). Dijalan tersebut terdapat banyak bangunan, toko-toko serta restoran. Jalan tersebut termasuk jalan yang padat aktifitas, apalagi pada pagi hari dan siang hari karena jalan ini merupakan jalan penghubung antara jalan Rasuna Said dan jalan Purus dimana disana terdapat banyak perkantoranperkantoran.

Berdasarkan uraian di atas, mengingat besarnya manfaat tanaman dalam menyerap polutan dan besaranya kemampuan tanaman glondokan dalam menyerap polutan dibandingkan tanaman mahoni dan angsana, maka peneliti malakukan penelitian mengenai perbedaan kadar $\mathrm{Pb}$ di tanaman peneduh di jalan Ujung Gurun Kota Padang. Rumusan masalah dari penelitian ini yaitu apakah ada perbedaan jenis tanaman dalam penyerapan logam berat $\mathrm{Pb}$ udara di Jalan dengan tujuan untuk mengetahui kadar $\mathrm{Pb}$ di daun tanaman mahoni, angsana dan glondokan serta mengetahui perbedaan kadar $\mathrm{Pb}$ pada masing-masing daun beberapa tanaman di jalan Ujung Gurun Kota Padang.

\section{METODE PENELITIAN}

Jenis penelitian yang adalah Analitik dengan pendekatan studi komparatif. Populasi pada penelitian ini adalah jenis tanaman mahoni, angsana dan glondokan yang ada di sepanjang jalan Ujung Gurun Kota Padang. Sampel diambil dengan menggunakan teknik purposive sampling dimana sampel diambil sesuai kriteria yang sudah ditentukan oleh peneliti itu sendiri. Penelitian dilakukan dengan cara pengambilan sampel daun tanaman yang dilakukan sebanyak 5 kali pengukuran dalam 1 hari pada 3 titik pengukuran dan melakukan pengukuran suhu, kelembapan, arah angin, kecepatan angin serta kepadatan kendaraan. Pengkuran dilakukan sebanyak 5 kali pengukuran, karena untuk validasi uji komparatif minimal pengukuran dilakukan sebayak 5 kali.

Pengambian sampel dilakukan dengan cara memotong daun pada masing-masing tanaman dengan menggunakan gunting, dan simpan di dalam plastik klep dan lakukan pengukuran luas permukaan daun. Pengukuran suhu dan kelembapan dilakukan dengan menggunakan Thermo Higrometer, pengukuran kecepatan angin dan arah angin menggunakan Anemometer, dan kepadatan kendaraan dihitung dengan Counter selama 1 jam. Pengukuran kadar $\mathrm{Pb}$ dilakukan dengan metode pengabuan basah, dimana sampel di potong kecil-kecil dan di keringkan didalam oven selama 10 jam. Sampel ditimbang 2-4 gram dan dimasukkan ke dalam erlemenyer dan dihaluskan. Tambahkan $10 \mathrm{ml} \mathrm{HNO}_{3}$ (65\%) dan dipanaskan, tambahkan $12 \mathrm{ml} \mathrm{H}_{2} \mathrm{O}_{2} 30 \%$ sedikit demi sedikit hingga gasnya hilang. Dinginkan larutan dan tambahkan akuades sebanyak $25 \mathrm{ml}$. Saring larutan dengan kertas Whatman dan masukka sampel ke dalam botol vial. Siapkan alat AAS (Atomic Absorption Spektrophotometer) dan lakukan analisis. 
Teknik pengumpulan data yang didapatkan dalam penelitian ini yaitu berupa data primer dan data sekunder. Data rimer berupa data yang didapatkan lansung pada saat penelitian, dilakukan dengan pengukuran lansung terhadap variabel-variabel yang diteliti. Sedangkan data sekunder didapatkan dari data Dinas Lingkungan Hidup, Badan Pusat Statistik serta penelitian-penelitian terdahulu. Perbedaan kadar $\mathrm{Pb}$ pada daun Angsana, Mahoni dan Glondokan dilakukan menggunakan uji Homogenitas, Anova dan Post Hoc.

\section{HASIL PENELITIAN}

Dari penelitian yang dilakukan, didapatkan hasil berupa pengukuran klimatologi seperti arah angin, kecepatan angin, suhu dan kelembapan serta kepadatan kendaraan, dan dilakukan pengukuran sampel kadar $\mathrm{Pb}$ di tanaman.

\section{Pengukuran Klimatologi}

Dari penelitian yang dilakukan didapatkan hasil pengukuran sebagai berikut :

Tabel 1. Pengukuran Kecepatan Angin, Suhu, dan Kelembapan dan Kepadatan Kendaraan di Jalan

\begin{tabular}{|c|c|c|c|c|c|c|}
\hline \multirow{2}{*}{$\begin{array}{c}\text { Nama } \\
\text { Titik }\end{array}$} & \multicolumn{6}{|c|}{ Pengukuran } \\
\hline & Waktu & $\begin{array}{c}\text { Arah } \\
\text { Angin }\end{array}$ & $\begin{array}{l}\text { Kecepatan } \\
\text { Angin }(\mathrm{m} / \mathrm{s})\end{array}$ & $\begin{array}{l}\text { Suhu } \\
{ }^{\circ} \mathrm{C}\end{array}$ & $\begin{array}{c}\text { Kelembapan } \\
\%\end{array}$ & $\begin{array}{c}\text { Kepadatan } \\
\text { Kendaraan } \\
\text { (kendaraan/jam) }\end{array}$ \\
\hline \multirow{7}{*}{ Titik 1} & $07.00-08.00$ & Barat & 1,13 & 28,1 & 66 & 2.816 \\
\hline & $10.00-11.00$ & Barat & 1,12 & 32 & 54 & 1.408 \\
\hline & $12.00-13.00$ & Barat & 1,02 & 34,7 & 49 & 2.313 \\
\hline & $15.00-16.00$ & Barat & 1,15 & 32,3 & 53 & 1.466 \\
\hline & $17.00-18.00$ & Barat & 1,18 & 28,9 & 63 & 1.232 \\
\hline & $07.00-08.00$ & Barat & 1,09 & 28,9 & 65 & 2.783 \\
\hline & $10.00-11.00$ & Barat & 1,08 & 32 & 54 & 1.507 \\
\hline \multirow[t]{5}{*}{ Titik 2} & $12.00-13.00$ & Barat & 0,97 & 35,8 & 49 & 2.286 \\
\hline & $15.00-16.00$ & Barat & 0,15 & 34,6 & 50 & 1.450 \\
\hline & $17.00-18.00$ & Barat & 0,16 & 29,7 & 63 & 1.214 \\
\hline & $07.00-08.00$ & Barat & 1,06 & 30,7 & 58 & 2.794 \\
\hline & $10.00-11.00$ & Barat & 0,94 & 31,67 & 56 & 1.382 \\
\hline \multirow[t]{3}{*}{ Titik 3} & $12.00-13.00$ & Barat & 0,54 & 35,5 & 49 & 2.273 \\
\hline & $15.00-16.00$ & Barat & 1,16 & 33,7 & 51 & 1.447 \\
\hline & $17.00-18.00$ & Barat & 1,31 & 29,7 & 63 & 1.194 \\
\hline
\end{tabular}

Dari data di atas dapat dilihat bahwa rata-rata arah angin yang ada di Jalan Ujung Gurun mengarah ke arah barat. Rata-rata kecepatan angin di Jalan Ujung Gurun 0,937 m/s dengan kecepatan angin tertinggi yaitu berada di titik 1 . Sedangkan rata-rata suhu udara di Jalan Ujung Gurun $31,8^{\circ} \mathrm{C}$ dengan suhu tertinggi berada di titik 3. Rata-rata kelembapan di Jalan Ujung Gurun 56,2\% dengan kelembapan tertinggi berada di titik 2. Dan rata-rata jumlah kendaraan bermotor yang melewati jalan ujung gurun 1.837 kendaraan/jam dengan kepadatan kendaraan tertinggi berada pada titik 2 . 


\section{Pengukuran Kadar $\mathrm{Pb}$ pada Tanaman}

Pengukuran sampel daun di 3 titik jalan Ujung Gurun sebagai berikut :

Tabel 2. Kadar Timbal (Pb) pada Daun Tanaman

\begin{tabular}{|c|c|c|c|c|c|}
\hline Pengukuran & $\begin{array}{c}\text { Kadar } \mathrm{Pb} \\
\text { daun } \\
\text { Mahoni ( } \\
\text { ug/g) }\end{array}$ & $\begin{array}{c}\text { Kadar } \mathrm{Pb} \\
\text { daun } \\
\text { Angsana ( } \\
\text { ug/g ) }\end{array}$ & $\begin{array}{c}\text { Kadar } \mathrm{Pb} \\
\text { daun } \\
\text { Glondokan } \\
(\mathrm{ug} / \mathrm{g})\end{array}$ & $\begin{array}{c}\text { Uji } \\
\text { Homogenitas }\end{array}$ & $\begin{array}{c}\text { Uji } \\
\text { Anova }\end{array}$ \\
\hline$(07.00-08.00)$ & 1,012 & 0,672 & 1,126 & \multirow{6}{*}{ Sig . 0,742 } & \multirow{6}{*}{$\begin{array}{c}\text { Sig. } \\
0,002\end{array}$} \\
\hline$(10.00-11.00)$ & 0,721 & 0,423 & 0,922 & & \\
\hline$(12.00-13.00)$ & 0,831 & 0,511 & 0,985 & & \\
\hline$(15.00-16.00)$ & 0,603 & 0,585 & 0,711 & & \\
\hline$(17.00-18.00)$ & 0,753 & 0,531 & 0,823 & & \\
\hline Rata-rata & 0,764 & 0,40 & 0,9134 & & \\
\hline
\end{tabular}

Dari data di atas dapat dilihat bahwa rata-rata kadar $\mathrm{Pb}$ yang ada pada daun tanaman yang paling tinggi yaitu daun tanaman glondokan $(0,9134 \mathrm{ug} / \mathrm{g})$. Kadar $\mathrm{Pb}$ di daun tanaman glondokan paling tinggi terdapat pada pukul 07.00-08.00 WIB sedangkan kadar $\mathrm{Pb}$ di daun tanaman glondokan terendah terdapat pada pukul 15.00-16.00 WIB. Dari hasil pengukuran yang didapatkan, dilakukan analisis data dengan menggunakan uji Homogenitas, uji Anova, dan uji Post Hoc.

Berdasarkan hasil uji homogenitas didapatkan nilai signifikansi sebesar 0,742 dimana $\mathrm{p}>0,05$ sehingga dapat disimpulkan bahwa data kadar timbal $(\mathrm{Pb})$ pada tanaman mahoni, angsana dan glondokan adalah bervariasi homogen. Berdasarkan Tabel uji Anova didapatkan nilai signifikansi sebesar 0,002 dimana $p<0,05$, sehingga dapat disimpulkan bahwa ada perbedaan jenis tanaman dalam penyerapan kadar timbal (Pb) udara di jalan ujung gurun kota padang tahun 2020. Berdasarkan hasil uji Post Hoc didapatkan perbedaan yang paling nyata dan yang paling nyata yaitu terdapat pada pohon mahoni dan glondokan.

\section{PEMBAHASAN}

Dari hasil penelitian didapatkan bahwa daun tanaman yang mempunyai daya serap tinggi terhadap polutan $\mathrm{Pb}$ yaitu tanaman glondokan. Dalam penelitian Indah Sulistyo Ningrum (2016), tanaman mahoni dapat menyerap kadar Pb udara sebanyak 1,16 $\mu \mathrm{g} / \mathrm{g}$, tanaman angsana sebanyak $1,57 \mu \mathrm{g} / \mathrm{g}$, dan tanaman glondokan sebanyak $1,88 \mu \mathrm{g} / \mathrm{g}$. Dengan ini dapat dikatakan bahwa tanaman glondokan lebih banyak menyerap kadar $\mathrm{Pb}$ di udara dibandingkan tanaman Mahoni dan Angsana. ${ }^{10} \mathrm{Hal}$ tersebut diduga karena beberapa faktor yaitu tinggi pohon, luas permukaan daun, tajuk dan tebal daun, percepatan pertumbuhan tanaman, cuaca dan kepadatan kendaraan. Tinggi pohon tanaman glondokan berkisar antara $5 \mathrm{~m}$, tinggi pohon tanaman mahoni $15 \mathrm{~m}$, sedangkan tinggi pohon tanaman angsana $15 \mathrm{~m}$. Jarak daun glondokan dengan permukaan tanah yaitu 0,5 m, jarak daun 
mahoni dengan permukaan tanah 2,5 m dan jarak daun angsana dengan permukaan tanah $2 \mathrm{~m}$.

Dalam penelitian Indah Sulistyo Ningrum (2016), menyatakan bahwa tinggi pohon dan posisi daun berpengaruh terhadap kemampuannya menyerap timbal. ${ }^{10}$ Semakin rendah suatu pohon dan jarak daun dengan permukaan tanah, maka daya serap polutan pohon tersebut juga semakin besar. ${ }^{12}$ Karena polutan $\mathrm{Pb}$ yang ada di udara akan cepat turun dnn menenmpel pada permukaan daun tanaman. Dengan ini dapat dikatakan bahwa tanaman glondokan mempunyai kemampuan yang besar dalam menyerap polutan. Selain itu, luas permukaan daun juga merupakan salah satu faktor yang dapat mempengaruhi kemampuan tanaman dalam penyerapan polutan. Dari hasil penelitian didapatkan luas permukaan daun glondokan yaitu $56 \mathrm{~cm}^{2}$. Luas permukaan tanaman mahoni yaitu $49,5 \mathrm{~cm}^{2}$ sedangkan luas permukaan daun angsana 45,24. Dalam penelitian Indah Sulistyo Ningrum (2016) menyatakan bahwa dengan adanya permukaan daun yang luas maka kemampuan untuk menyerap atau menahan timbal lebih banyak. ${ }^{10}$ Untuk itu tanaman glondokan mempunyai kemampuan besar dalam menyerap poluan yang ada di udara. Daun tanaman glondokan memiliki bentuk daun yang memanjang serta tajuk yang rapat dan menjarum ke atas. Sementara tanaman mahoni memiliki bentuk daun oval memanjang serta tajuk daun yang renggang dan mengembang. Sedangkan tanaman angsana memiliki bentuk daun bulat memanjang serta tajuk daun yang renggang dan mengembang.

Dalam penelitian Tambaru 2018, semakin tebal daun akan menyebabkan gas pencemar sulit menembus jaringan daun sehingga masuknya gas pencemar relatif kecil atau gas yang terserap oleh daun relatif lebih rendah, sedangkan pada daun yang tipis gas lebih mudah terserap. Dan semakin rapat dan tebal suatu tajuk tanaman maka semakin tinggi kemampuan tanaman dalam menyerap polutan. ${ }^{12}$ Polutan di udara akan mudah terbawa oleh kecepatan angin. Apabila suatu tajuk tanaman rapat, maka kemampuan kecepatan angin membawa polutan rendah, karena daun tanaman akan menyerap polutan-polutan tersebut. Untuk itu, karena tajuk tanaman tanaman glondokan rapat dan padat maka tanaman glondokan dapat menyerap polutan diudara lebih banya karena keadaan tajuk tanaman tersebut yang rapat, sehingga polutan yang terbawa oleh kecepatan angin tetap menempel pada daun tanaman tersebut. ${ }^{14}$ Tanaman glondokan mahoni dan angsana mempunyai kecepatan pertumbuhan yang berbeda-beda. Tanaman glondokan mempunyai percepatan pertumbuhan selama 3 tahun. Tanaman mahoni mempunyai kecepatan pertumbuhan 7 tahun, sedangkan tanaman angsana memiliki kecepatan pertumbuhan 7-9 tahun. Dalam Penelitian Abdul Hafiz (2014), mengatakan semakin cepat suatu tanaman tumbuh maka kemampuan daun tersebut dalam menyerap polutan juga lebih besar. ${ }^{13}$

Untuk itu tanaman glondokan mempunyai peluang lebih tinggi dalam penyerapan polutan karena tanaman ini mempunyai percepatan tumbuhan yang cepat. Kemampuan 
suatu tanaman dalam menyerap kadar polutan di udara tidak hanya dipengaruhi oleh faktor tanaman tersebut, namun faktor lingkungan tanaman tersebut juga mempengaruhi kemampuan tanaman dalam menyerap polutan. Dalam penelitian Winardi (2014), naiknya temperatur akan menyebabkan konsentrasi $\mathrm{Pb}$ di udara menjadi turun karena pada suhu yang lebih tinggi udara akan lebih mudah memuai yang menyebabkan konsentrasi polutan menjadi lebih encer (dilusi). Pada waktu pagi suhu di permukaan bumi lebih rendah dibandingkan pada siang hari dan sore hari, sehingga menyebabkan konsentrasi $\mathrm{Pb}$ dipermukaan bumi pada pagi hari lebih tinggi dibandingkan siang hari dan sore hari. Selain itu di pagi hari kondisi atmosfir yang tidak stabil akan menyebabkan konsentrasi polutan cenderung tertahan dipermukaan bumi dan tidak terdispersi secara vertikal ke atmosfir. Naiknya angka kelembaban menyebabkan naiknya konsentrasi polutan. Pada udara yang lebih lembab polutan tidak gampang untuk berpindah secara vertikal ke atas, dan lebih sulit untuk terencerkan. ${ }^{14}$

Bedasarkan hasil penelitian Choirunnisa (2012) menyatakan, pengaruh cahaya memang merupakan peranan penting dalam berlansungnya proses tanaman dalam menyerap polutan. Dimana pada saat adanya cahaya matahari, stomata daun akan terbuka lebih lebar sehingga gas pencemar lebih banyak terserap oleh tanaman. ${ }^{15}$ Dari hasil penelitian, suhu udara tertinggi $35,8^{\circ} \mathrm{C}$ dengan kelembapan $49 \%$. Pada saat penelitian, kota Padang sedang dilanda musim kemarau, dimana pada saat itu di kota Padang jarang terjadi hujan. Dengan keadaan seperti ini, polutan-polutan yang ada yang dihasilkan oleh kendaraan bermotor akan tetap berada di udara karena tidak terjadi pengenceran polutan tersebut. Dengan keadaan cuaca yang panas stomata daun akan terbuka dan polutan-polutan yag ada di udara akan lebih banyak diserap oleh tanaman. Selain suhu dan kelembapan, arah dan kecepatan angin juga merupakan faktor yang memepengaruhi kemampuan tanaman dalam menyerap polutan.

Bedasarkan hasil penelitian Kiki Ramayana (2013), secara keseluruhan hubungan kecepatan angin terhadap polutan di udara adalah berbanding terbalik, semakin tinggi kecepatan angin maka polutan yang ada di udara akan berkurang. Semakin cepat angin bertiup maka semakin luas sebaran daerah yang terkena polusi udara yang menyebabkan konsentrasi polutan kecil. ${ }^{16}$.Dari hasil penelitian yang dilakukan, arah angin di Jalan Ujung Gurun mengarah ke arah barat. Dan rata-rata kecepatan angin di jalan tersebut 0,937 m/s. Kecepatan angin di jalan tersebut masih dalam kondisi lemah. Dengan keadaan seperti ini, polutan yang ada di jalan tersebut masih banyak menetap di udara dan belum terbawa oleh kecepatan angin ke mana-mana karena kecepatan angin yang ada di jalan tersebut masih lemah. Selain faktor klimatologik, kepadatan lalu lintas juga merupakan faktor yang mempengaruhi tanaman dalam menyerap polutan. Seperti yang kita ketahui, bahwa kepadatan lalu lintas merupakan faktor utama terjadinya pencemaran udara. Menurut Indah 
Sulystio (2016), Semakin banyak kendaraan yang lewat maka kerapatan stomata daun juga semakin banyak, sehingga daun tersebut dapat menyerap kadar logam berat dalam jumlah yang banyak pula. ${ }^{11}$ Dari hasil penelitian, rata-rata kepadatan kendaraan di jalan ujung gurun yaitu 1.837 kendaraan/jam. Di jalan tersebut sering terjadi kemacetan apalagi pada pagi hari dan siang hari. Karena jalan ini terdapat perkantoran, sekolah, dan restoranrestoran. Letak tanaman glondokan, mahoni dan angsana berada di tepi jalan sepanjang jalan. ${ }^{11}$

Berdasarkan hasil penelitian yang dilakukan, didapatkan kadar $\mathrm{Pb}$ pada tanaman paling tinggi terdapat pada pukul 07.00 WIB. Hal ini terjadi karena pada saat itu cahaya terang dan kendaraan yang melewati jalan tersebut ramai bahkan mengakibatkan kemacetan. Tidak hanya itu, kecepatan angin masih temasuk kategori lemah, sehingga polutan-polutan yang ada di udara masih terakumulasi di lokasi tersebut. Dengan keadaan seperti demikian, stomata tanaman akan terbuka lebih besar karena cahaya terang dan kendaraan yang lewat ramai. Sehingga dengan stomata daun yang terbuka lebar, kecepatan angin masih lemah, dan banyaknya kendaraan yang melewati jalan tersebut, sehingga daun tanaman tersebut dapat menyerap polutan yang ada di udara dalam jumlah yang besar. Untuk itu dari hasil penelitian yang dilakukan, dalam melakukan penanaman tanaman yang akan di tanam di jalan, kita harus memperhatikan fisiologi tanaman tersebut. Seperti tinggi pohon dan jarak daun tanaman yang paling dekat dengan permukaan tanah, luas permukaan daun tanaman yang besar, percepatan pertumbuhan tanaman yang cepat, dan ketebalan daun dan tajuk tanaman yang rapat serta padat.

\section{SIMPULAN DAN SARAN}

Bedasarkan hasil peneitian yang di dapatkan, Kadar timbal pada daun mahoni di Jalan Ujung Gurun Kota Padang yaitu $0,8324 \mu \mathrm{g} / \mathrm{g}$. Kadar timbal pada daun angsana yaitu 0,4 $\mu \mathrm{g} / \mathrm{g}$. Kadar timbal pada daun glodokan yaitu $0,91 \mu \mathrm{g} / \mathrm{g}$. Dan hasil ini menunjukkan ada perbedaan yang signifikan terhadap jenis tanaman dalam penyerapan kadar logam berat pb udara di jalan Ujung Gurun kota Padang. Untuk itu diupayakan penanaman pohon hijau yang bervariasi pada ruas jalan yang padat lalu-lintas dan melakukan sosialisasi kepada masyarakat untuk senantiasa memelihara pohon serta memberikan kebijaksanaan bahan bakar yang diikuti dengan serangkaian kegiatan terpadu dengan mengacu pada bahan bakar bersih dan ramah lingkungan kepada masyarakat.

\section{DAFTAR PUSTAKA}

1. Peraturan Menteri Negara Lingkungan Hidup Nomor 12 Tahun 2010 Tentang Pelaksanaan Pengendalian Pencemaran Udara Di Daerah.

2. Nihayatul S. Kandungan Pb Pada Daun Angsana ( Pterocarpus indicus )dan Rumput 
Gajah Mini (Axonpus.Sp) Di Jalan Protoko Kota Tanggerang. Valensi. 2010;2(1):340346.

3. Dwi Pamit, Martuti Nana BFP. Uji Kandungan Timbal $(\mathrm{Pb})$ daam Daun Tanaman Peneduh Di Jalan Protokol Kota Semarang. Biosantifika. 2014;6(1).

4. Hendrasarie N. Kajian Efektiitas Tanaman Dalam Menjerap Kandungan Pb di Udara. Rekayasa Perenc. 2017;3(2).

5. Nana M. Peranan Tanaman Terhadap Pencemaran Udara Di Jalan Protokol KOta Semarang. Biosantifika. 2013;5(1).

6.. Nurmasari. Pengaruh emisi kendaraan bermotor terhadap ukuran dan kerapatan trikoma. 2018.

7. Hindratmo B, Junaidi E, Masitoh S, Fauzi R. Kemampuan 11 ( Sebelas ) Jenis Tanaman dalam Menyerap Logam Berat Timbel ( $\mathrm{Pb}$ ) Capabilities 11 ( Eleven ) Species to Reduce Lead ( Pb ) Pollution. Ecolab. 2019;13(1):1-60.

8. Pemerinah Provinsi Sumaera Barat Buku Data Status Lingkungan Hidup Daerah.; 2019.

9. Sufariz R. Uji Kandungan Logam Berat Pb Pada Tanaman Peneduh Dijalan Protokol Kota Bandung. Biosantifika. 2016.

10. Indah N. Kandungan Timbal (Pb) Pada Tanaman Peneduh Di Jalan Tuanku Tambusai Pekanbaru. Jom Vaperta UR. 2016;3(1).

11. Riska M. Jumlah Ukuran Stomata pada Daun Glondokan Di JalanTun Abdu Razaq Dan Di Area Kampus UIN Alaudin Makassar. 2015.

12. Tambaru E, Paembonan SA, Sanusi D, Umar A. Karakter morfologi dan tipe stomata daun beberapa jenis pohon penghijauan hutan kota di kota makassar. 2011.

13. Al-hakim AH. Evaluasi Efektivitas Tanaman Dalam Mereduksi Polusi Bedasarkan Karakteristik Fisik Pohon Pada Jalur Hijau Pajajaran Bogor. 2014.

14. Winardi. Pengaruh Suhu Dan Kelembaban Terhadap Konsentrasi Pb di Udara Kota Pontianak. Issn 2356-136X. 2014;01(1):16-25.

15. Choirunnisa D. Identifikasi Stuktu Anatomi Daun Angsana Dan Beringin Akibat Pengaruh Gas Dan Materi Vulkanik Pasca Erupsi Gunung Merapi. 2012.

16. Ramayana K, Istirokhatun T. Pengaruh Jumlah Kendaraan Dan Faktor Meteorologis Terhadap Peningkatan Konsentrasi Gas Pencemar Co Pada Persimpangan Jalan Kota Semarang. 2013. 